\title{
5. EOCENE TO PLIOCENE CORALLINE ALGAE IN THE QUEENSLAND PLATEAU (NORTHEASTERN AUSTRALIA) ${ }^{1}$
}

\author{
José M. Martín ${ }^{2}$ and Juan C. Braga ${ }^{2}$
}

\begin{abstract}
Sediments containing coralline algae in the Queensland Plateau range from the middle Eocene to the early Pleistocene in age. In the middle Eocene sediments, the corallines occur as highly fragmented and eroded particles in temperate, platform carbonates (grainstones and rudstones) with abundant bryozoans, benthic foraminifers, and bivalves. They occasionally interbed with thin intervals of tropical to subtropical sediments that contain abundant Halimeda, coral debris, and coralline fragments, mainly of Lithoporella and Mesophyllum. In the upper Oligocene sediments, similar temperate carbonates, in which small, scarce, unidentifiable coralline fragments can be seen, also occur.

The lower Miocene platform carbonates consist of grainstones and packstones having a tropical assemblage with corals and Halimeda, together with a shallow-water coralline association of geniculate (Jania, Corallina, Amphiroa) and encrusting forms (Lithoporella and Spongites). Allochthonous fragments of geniculate and encrusting corallines (Mesophyllum and Lithothamnion) of early Miocene age occur in clasts in bioclastic floatstones (debris-flow deposits) of middle Miocene age. The algal composition points to an outer-shelf origin for these clasts.

The middle Miocene carbonate sediments that contain corallines are also tropical and consist of bioclastic packstones to wackestones, with Halimeda, and corals. Coralline-algal debris is predominantly composed of loose, abraded, branching thalli of Sporolithon and Lithothamnion, and small rhodoliths (up to $2 \mathrm{~cm}$ ). The nuclei of most of the rhodoliths consist of a small branch fragment. They are encrusted by laminar growths of Lithothamnion, Mesophyllum, Hydrolithon, and Sporolithon. Some fragments of the rare coralline genus Aethesolithon also have been found. The depositional environment is that of a low-energy, neritic, open platform, as can be deduced from the predominance of delicate branching growths, the smaller size of the rhodoliths, the abundance of fine-grained sediments, and the scarceness of reworking.

Lower Pliocene corallines occur as redeposited elements in debris flows. They appear mainly as very thin laminae in foralgaliths that are intimately associated with encrusting foraminifers. The most common alga is Lithoporella.

The present-day, shallow-water, reefal coralline associations dominated by members of the subfamily Mastophoroideae were not detected in any of the sediments drilled in the Queensland Plateau.
\end{abstract}

\section{INTRODUCTION}

Coralline algae were common components of the shelf carbonates deposited in the Queensland Plateau area during the Tertiary period. Samples containing corallines can be found in all the sites drilled in the Queensland Plateau. These sites are located in two different areas (Fig. 1): at the western margins of the plateau adjacent to the Queensland Trough (Sites 823,824 and 811/825), and at the southern margins adjacent to the Townsville Trough (Sites 812, 813, 814, and 817). Coralline algae are found in the western part in lower Pliocene (Site 824), lower Miocene (Sites 823 and 824), upper Oligocene (Site 824), and middle Eocene (Site 825 ) samples. All the corallines found in the southern part (Sites $812,813,814$, and 817 ) belong to the middle Miocene. The degree of recovery and preservation changes from site to site; however, the coralline record is generally good enough to allow a detailed study of the algae. Coralline algae can be used as paleobathymetric as well as paleoclimatic indicators, although further studies on their distribution in fossil and modern environments are needed to specifically determine their paleoenvironmental significance. The available data show changes in coralline algal associations and coralline morphology in response to changes in water depth and turbulence, as well as the presence of distinct coralline floras in the different climatic belts (see Adey and McIntyre, 1973; and Bosence, in press, for a summary). In this report, these data have been used together with other sedimentological and paleontological evidence to

\footnotetext{
${ }^{1}$ McKenzie, J.A., Davies, P.J.. Palmer-Julson. A.. 1993. Proc. ODP. Sci. Results, 133: College Station. TX (Ocean Drilling Program).

2 Departamento de Estratigrafía y Paleontología e Instituto Andaluz de Geología Mediterránea, Facultad de Ciencias, Universidad de Granada, Campus de Fuentenueva s.n. 18002 Granada, Spain.
}

interpret the paleoenvironments of the Tertiary sediments containing red algae drilled from the Queensland Plateau.

\section{METHODS}

Sixty-nine thin sections of samples from all the sites located in the Queensland Plateau were studied, and the carbonate petrography and coralline algae (types, growth forms, and associations) determined. Samples were taken whenever corallines appeared in the cores (Figs. 2 and 3). A detailed list of the samples for each specific time interval and site is given below.

\section{THE CORALLINE FACIES: TEMPORAL DISTRIBUTION AND CHARACTERISTICS}

\section{Middle Eocene}

All the samples containing corallines from the middle Eocene belong to Site 825, lithologic Unit VI (Samples 133-825B-6R-1, $27-29 \mathrm{~cm}$, and $54-56 \mathrm{~cm}$; $133-825 \mathrm{~B}-7 \mathrm{R}-1,32-33 \mathrm{~cm}$, and $68-71 \mathrm{~cm}$; and $133-825 \mathrm{~B}-8 \mathrm{R}-1,0-12 \mathrm{~cm}$, and $19-21 \mathrm{~cm}$ ), the precise age of which recently has been determined by Betzler and Chaproniere (this volume). These are grainstones and rudstones (sometimes floatstones) having abundant fragments of bryozoans, benthic foraminifers, coralline algae, intraclasts, gastropods, echinoids, and bivalves. Coralline algal remains in general are poorly preserved and unidentifiable. Some samples (such as 133-825B-6R-1, 54-56 cm, and 133-825B-7R-1, $32-33 \mathrm{~cm}$ ) exhibit frequent coral and Halimeda fragments. Poorly preserved remains of Lithoporella have been identified in these samples. Fragments of Mesophyllum, Spongites, Lithothamnion, Jania, and Corallina also can be recognized (PI. 1, Fig. 1). 


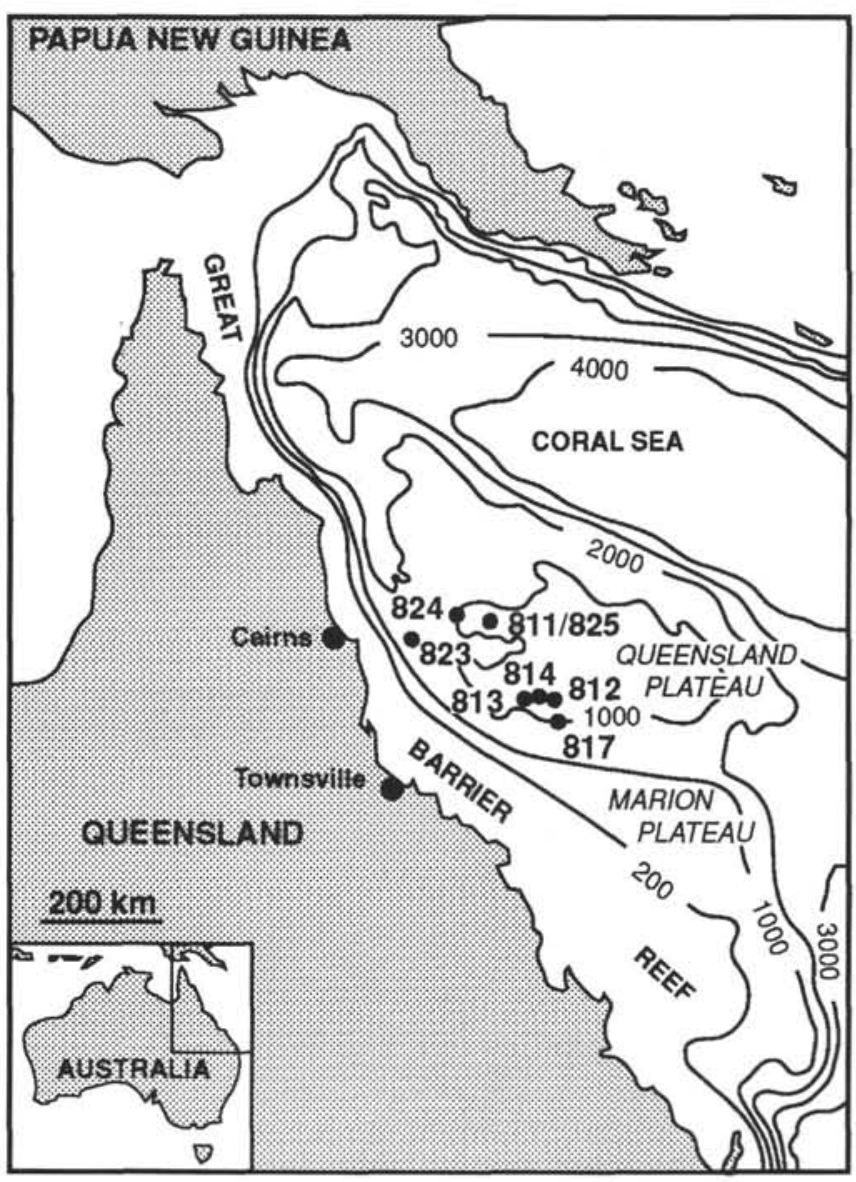

Figure 1. Geographical location of Sites 812,813,814, and 817 and Sites 823 . 824 , and $811 / 825$ at the southern and western margins of the Queensland Plateau, respectively.

\section{Late Oligocene}

The two samples studied containing corallines from the late Oligocene belong to Unit VI of Site 824 (Samples 133-824A-36X-CC, $20-22 \mathrm{~cm}$, and $31-34 \mathrm{~cm}$ ). These are foraminiferal/bryozoan packstones/grainstones (rudstones) having echinoids, gastropods, intraclasts and corallines, with the latter being scarce, highly fragmented, and completely unidentifiable.

\section{Early Miocene}

Lower Miocene sediments containing corallines can be found in lithologic Subunit VB, Site 824 , initially considered to be of middle to late Miocene age (Shipboard Scientific Party, 1991h, Site 824), but later dated as early Miocene by Betzler and Chaproniere (this volume). The corallines also occur as redeposited debris within middle Miocene sediments (again see datings by Betzler and Chaproniere, this volume) in Unit VII, Site 823. The samples studied are from Site 824: 133-824A-29X-CC, 0-18 cm; 133-824A-30XCC, $0-17 \mathrm{~cm}$; and $133-824 \mathrm{C}-8 \mathrm{R}-1,45-50 \mathrm{~cm}, 61-63 \mathrm{~cm}$, and $91-96$ $\mathrm{cm}$; and Site 823: 133-823C-13R-2, 122-125 cm, and 133-823C$13 \mathrm{R}-4,31-36 \mathrm{~cm}$.

Lower Miocene platform carbonates from Site 824 consist of packstones/grainstones/rudstones having fragments of coralline algae, benthic foraminifers (sometimes abundant), and rare planktonic foraminifers, gastropods, bivalves, echinoids, corals (some of them encrusted by corallines and foraminifers), Halimeda, and a few detrital grains. Among the corallines, Lithoporella is dominant (Pl. 1, Fig. 2).
Redeposited early Miocene corallines are found in shallow-water, platform-derived pebbles and clasts in debris flows (bioclastic floatstones) of middle Miocene age, together with fragments of Halimeda, foraminifers, bryozoans, bivalves, echinoids, and corals (Shipboard Scientific Party, 1991g, Site 823). The coralline association is here composed of Mesophyllum, Lithothamnion, and geniculate corallines (Jania and Corallina) (Pl. 1, Fig. 3).

\section{Middle Miocene}

The middle Miocene samples containing corallines were found at Sites $812,813,814$, and 817 , all of which are located in the southern part of the Queensland Plateau. At the first three sites, these corallines are autochthonous, but at Site 817 they appear to be redeposited clasts and pebbles in debris flows.

At Site 812, all of the samples belong to lithologic Unit III, in which three subunits, considered to be of lagoonal and/or back-reef origin, were differentiated (Shipboard Scientific Party, 1991c, Site 812). Most of the samples come from Subunit IIIA. These include 133-812A-18X$1,7-8 \mathrm{~cm}$, and $32-33 \mathrm{~cm}$; $133-812 \mathrm{~A}-18 \mathrm{X}-\mathrm{CC}, 8-9 \mathrm{~cm} ; 133-812 \mathrm{~A}-$ 19X-1, 11-12 cm; 133-812A-20X-1, 29-31 cm, and 93-95 cm; 133-812A-22X-1, 19-20 cm, and 44-45 cm; 133-812B-3R-1, 15-16 $\mathrm{cm}, 113-114 \mathrm{~cm}$, and $140-142 \mathrm{~cm} ; 133-812 \mathrm{~B}-3 \mathrm{R}-2,2-3 \mathrm{~cm}$, and 20-21 cm; $133-812 \mathrm{~B}-4 \mathrm{R}-1,24-25 \mathrm{~cm}$, and $51-52 \mathrm{~cm} ; 133-812 \mathrm{~B}-5 \mathrm{R}-$ $1,71-72 \mathrm{~cm}$, and $105-106 \mathrm{~cm} ; 133-812 \mathrm{~B}-6 \mathrm{R}-1,6-7 \mathrm{~cm}, 82-83 \mathrm{~cm}$, and $107-108 \mathrm{~cm} ; 133-812 \mathrm{~B}-7 \mathrm{R}-1,25-26 \mathrm{~cm}, 105-106 \mathrm{~cm}, 118-119$ $\mathrm{cm}$, and $127-128 \mathrm{~cm} ; 133-812 \mathrm{~B}-8 \mathrm{R}-1,2-3 \mathrm{~cm}, 28-29 \mathrm{~cm}$, and $32-33$ $\mathrm{cm}$; and 133-812B-9R-1, 24-25 cm, and 137-138 cm. From Subunit IIIB, the samples are 133-812B-10R-1, 24-25 cm, and 33-34 cm; $133-812 \mathrm{~B}-11 \mathrm{R}-1,1-2 \mathrm{~cm}$, and 133-812B-12R-1, 2-3 cm; from Subunit IIIC, 133-812B-18R-1, 5-7 cm, and 18-23 cm.

The coralline samples studied from Site 813 belong to Unit V, considered to be shallow neritic (Shipboard Scientific Party, 1991d, Site 813). These samples are 133-813A-25CC, at 2-3 cm and 21-22 $\mathrm{cm}$. Coralline samples at Site 814 are from the top of Unit IV, interpreted as a middle ramp or slope (Shipboard Scientific Party, 1991e, Site 814). These are 133-814A-17X-1, 20-21 cm, and 20-25 cm; and $133-814 \mathrm{~A}-18 \mathrm{X}-1,1-2 \mathrm{~cm}$. At Site 817 , in the Townsville Trough, the samples studied belong to Subunit IIIB, deposited in a base-of-slope debris apron (Shipboard Scientific Party, 1991f, Site 817). The samples are 133-817D-23R-1, 27-30 cm, and 32-33 cm; 133-817D-25R-1, $42-46 \mathrm{~cm}$; and 133-817D-33R-1, 68-71 cm.

The carbonate sediments containing corallines at Site 812 consist of dolomitized wackestones, packstones, and floatstones with benthic (and some planktonic) foraminifers, echinoids, dasyclad algae, bivalves, gastropods, Halimeda, bryozoans, and coral fragments, the latter sometimes encrusted by thin coralline laminae. Some samples from Subunit IIIC are rich in benthic foraminifers. Corallines occur as loose and abraded fragments of branching thalli and as small (less than $2 \mathrm{~cm}$ ), spheroidal-to-ellipsoidal rhodoliths. Most branching growths belong to Sporolithon (PI. 1, Fig. 4) and/or Lithothamnion. The internal structure of the rhodoliths is simple, with their nuclei being a branch fragment (normally Sporolithon), or occasionally a coral fragment covered by thin laminae of Lithothamnion (Pl. 1, Fig. 5) and Mesophyllum, sometimes accompanied by Hydrolithon. Encrusting foraminifers may be intergrown with coralline crusts within the rhodoliths, which also have been bored locally and exhibit small internal erosional surfaces. Fragments of Jania and Corallina are dispersed in the micritic matrix.

Loose fragments of Aethesolithon Johnson, bored by sponges, appear in some samples (PI. 2, Figs. 1 and 2). Aethesolithon was determined and has only been described by Johnson $(1961,1964)$ from the Miocene of Guam. Although it has a distinctive vegetative anatomy (with large cell fusions in the inner parts of the thallus), the status and affinities of this genus need revision. Some samples from the Queensland Plateau show uniporate conceptacles that closely resemble those of the genus Hydrolithon. 
TOWNSVILLE TROUGH TRANSECT

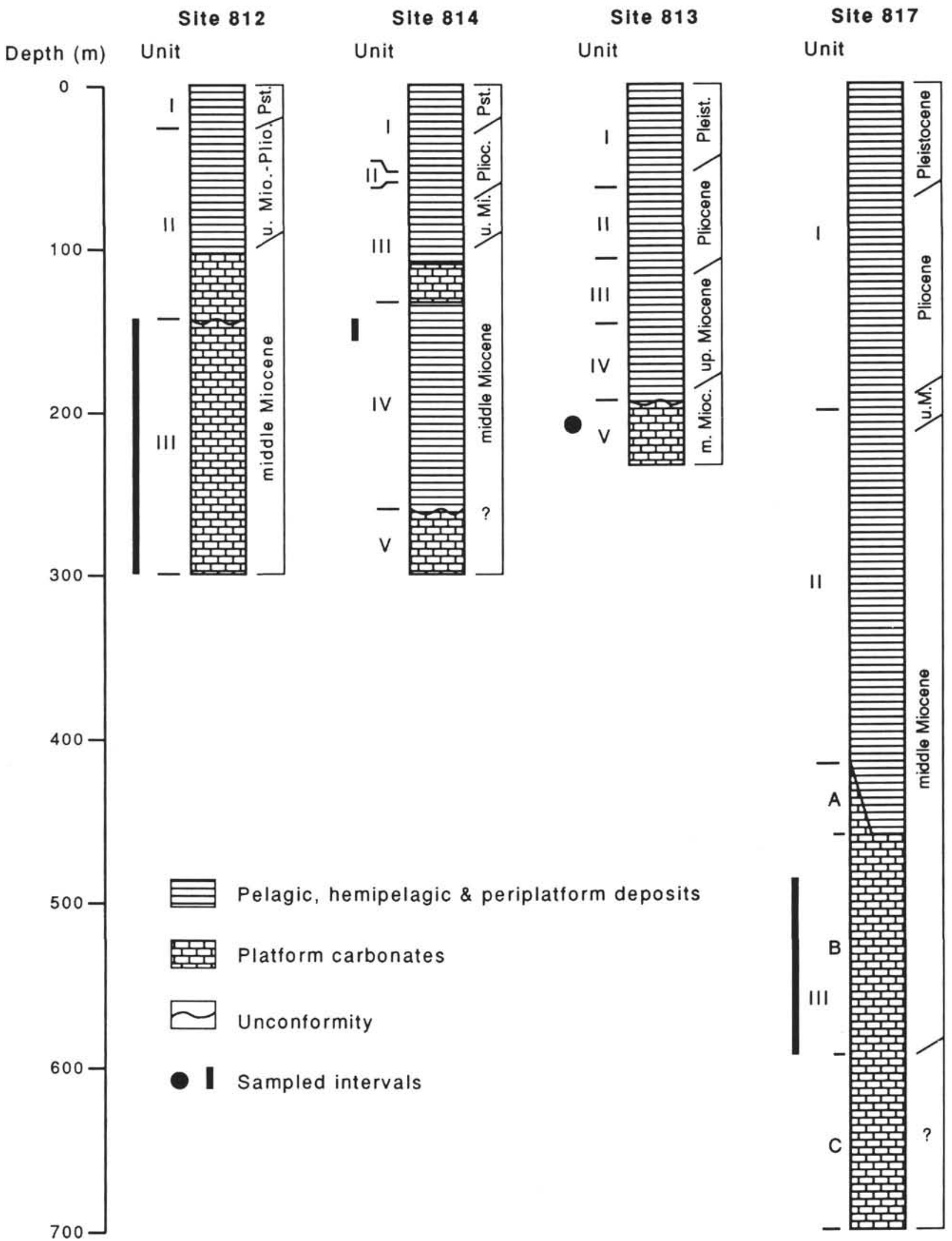

Figure 2. Townsville Trough transect. Simplified stratigraphic sections of Sites 812, 813, 814, and 817 (modified from Shipboard Scientific Party, 1991a, Fig. 2) with indications of units and positions of the coralline samples. 


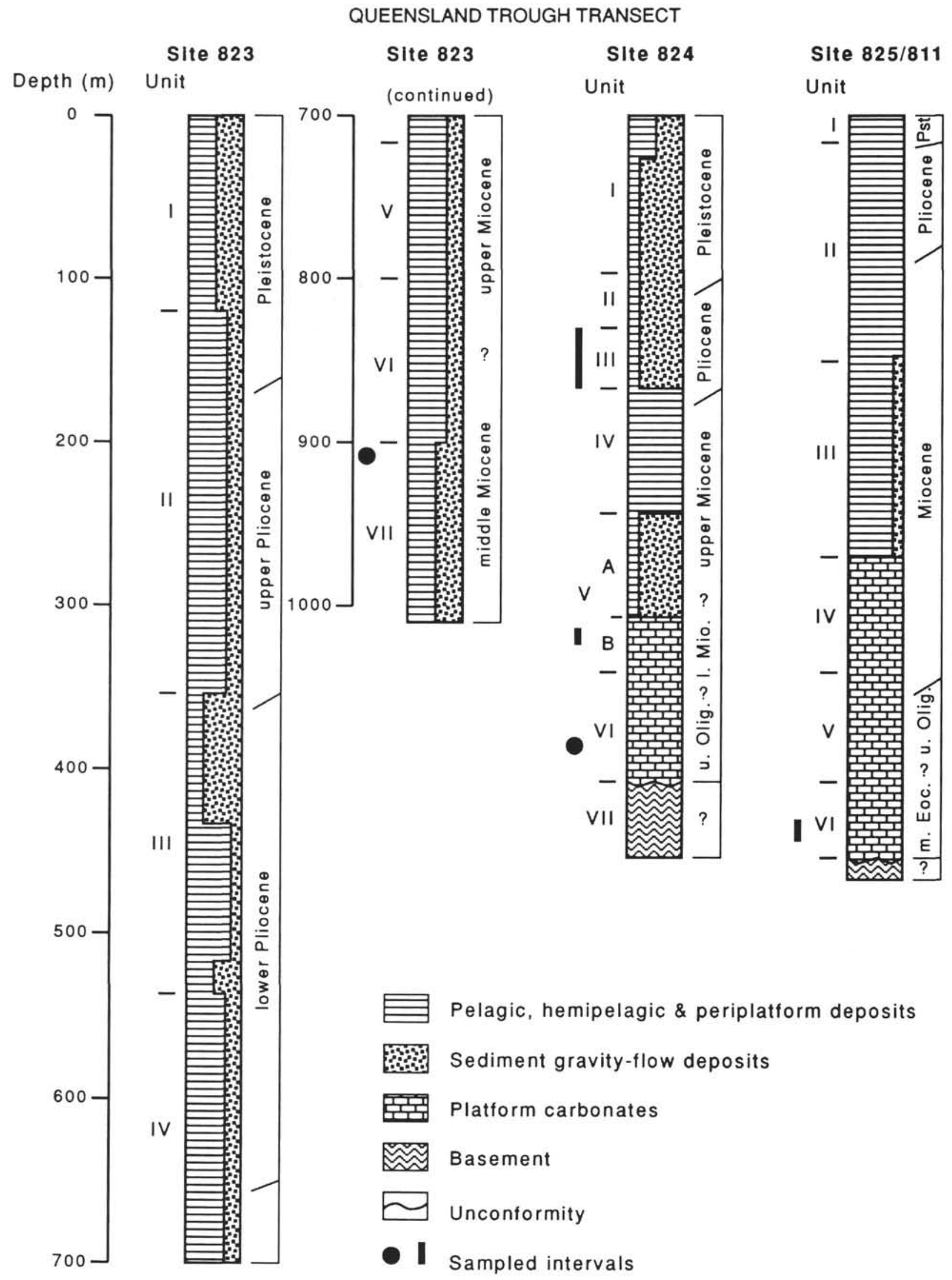

Figure 3. Queensland Trough transect. Simplified stratigraphic sections of Sites 823, 824, and 825 (modified from Shipboard Scientific Party, 1991a, Fig. 3) with indications of units and positions of the coralline samples. 
The three subunits of Site 812 (Shipboard Scientific Party, 1991c, Site 812) show the same coralline association. Much the same can be said of the facies.

Distal-slope, fine-grained carbonates with corallines occur at Sites 814 and 813 . These are wackestones having highly fragmented benthic (and rare planktonic) foraminifers, echinoids, and bivalves. The corallines are poorly preserved and are presumed to be the same genera as those appearing at Site 812 . Grain size progressively diminishes downslope westward from Site 812 to 814 and 813 .

Undolomitized or partially dolomitized bioclastic floatstones (debris flows) having abundant benthic and planktonic foraminifers, echinoids, bryozoans, gastropods, corals, Halimeda, intraclasts, and corallines occur as platform-derived sediments that have been redeposited in a deeper-water setting at Site 817 in the Townsville Trough. Rhodoliths similar to those of the Marion Plateau (see Martín et al., this volume) of Mesophyllum (PI. 1, Fig. 6) and Lithothamnion are found together with branching fragments of Sporolithon, Lithothamnion, and laminar crusts of Mesophyllum and Lithoporella that are identical to those appearing at Site 812 in the Queensland Plateau.

\section{Early Pliocene}

All of the lower Pliocene carbonates containing corallines are from Unit III, Site 824, and contain redeposited clasts of bioclastic rudstones and packstones that have been interpreted as debris-flow deposits (Shipboard Scientific Party, 1991h, Site 824). The samples studied are $133-824 \mathrm{~A}-10 \mathrm{H}-1,75-77 \mathrm{~cm}, 84-88 \mathrm{~cm}, 88-90 \mathrm{~cm}, 113-116 \mathrm{~cm}$, $132-138 \mathrm{~cm}$, and $140-143 \mathrm{~cm} ; 133-824 \mathrm{~A}-10 \mathrm{H}-\mathrm{CC}, 2-5 \mathrm{~cm}$, and 5-9 $\mathrm{cm}$; 133-824A-11X-CC, 2-5 cm; and 133-824A-14H-1, 48-50 cm.

Fragments of echinoids, benthic and planktonic foraminifers, bivalves, corals, bryozoans, and Halimeda can be found in the clasts, together with the corallines. These latter are mainly present in the form of thin laminar growths between thick layers of encrusting foraminifers inside foralgaliths (Pl. 2, Fig. 3). The term "foralgalith" was first introduced by Prager and Ginsburg (1989) to describe nodules consisting of encrusting foraminifer and coralline growths intimately associated. Lithoporella is dominant (PI. 2, Fig. 4). Lithothamnion and Mesophyllum also are found as minor components.

\section{CORALLINE PALEOENVIRONMENTS}

In the middle Eocene, corallines appear in typical temperate carbonates that were deposited on an inner-neritic shelf (Shipboard Scientific Party, 1991b, Site 811/825). However, because of the poor degree of preservation, coralline algae cannot be identified. In the intercalated intervals of tropical/subtropical carbonates with Halimeda and corals, Lithoporella is the commonest red alga. This genus is also characteristic of tropical/subtropical environments (Lemoine, 1976). The upper Oligocene corallines, highly fragmented and completely unidentifiable, are related again to inner-neritic, foraminiferal/bryozoan, temperate-platform carbonates (Shipboard Scientific Party, 1991h, Site 824).

The lower Miocene platform carbonates, with abundant coral and Halimeda fragments, have an unquestionable tropical character. At Site 824, some coralline debris (the mastophoroids Spongites and Neogoniolithon?) may suggest a shallow-water origin for these carbonates, but these algae now occur as reworked and fragmented particles, possibly incorporated into sand bars. The foraminiferal assemblages point to a similar environment (Betzler and Chaproniere, this volume). The redeposited lower Miocene coralline assemblage of Site 813, composed of Mesophyllum, Lithothamnion, and geniculate corallines (Jania and Corallina) (Pl. 1, Fig. 3), seems to come from a deeper setting (outer shelf) than that at Site 824 (see below).

The middle Miocene algal associations drilled at Site 812 are completely dominated (more than $80 \%$ of coralline thalli) by members of the subfamily Melobesioideae (nongeniculate coralline algae). This is characteristic of deep-water shelf environments in low-lati- tude areas in both fossil and recent examples (Bosence, in press). Although precise proportions of the different genera cannot be established due to the high number of unidentifiable fragments, these associations (composed mainly of Lithothamnion, Mesophyllum, and Sporolithon) are similar to those described by Adey (1979) in outer-platform settings at depths between 30 and $80 \mathrm{~m}$ in the present-day Pacific Ocean (Hawaiian Islands). The attribution of these facies to lagoonal or back-reef environments (Shipboard Scientific Party, 1991c, Site 812) may be incorrect.

These algal associations from the middle Miocene of the Queensland Plateau also are similar to those drilled in the middle Miocene of the Marion Plateau (see Martín et al., this volume), although some small differences do exist between the two areas. In the Marion Plateau, rhodoliths of up to $6 \mathrm{~cm}$ in size are dominant and exhibit several phases of growth and reworking (Martín et al., this volume). The sediments are normally washed, bioclastic calcarenites. In the Queensland Plateau, delicate, branching, and thin laminar growths embedded in a micrite-rich facies dominate. Marion Plateau rhodoliths are considered to have been formed in an outer-platform area that was influenced by sporadic storms (Martín et al., this volume). The Queensland corallines are thought to have grown in a comparable setting, although it was probably either less energetic (without significant storms) or slightly deeper.

At Site 817, the existence of redeposited rhodoliths, similar to those of the middle Miocene of the Marion Plateau, and transported branching coralline fragments, identical to those appearing in the middle Miocene of the Queensland Plateau, may suggest the existence of two sources for the sediments that arrived at the Townsville Trough during the middle Miocene.

In the lower Pliocene, coralline algae occur inside foralgaliths (in redeposited clasts) closely associated to encrusting foraminifers. Modern analogs of these foralgaliths with a similar algal composition have been recorded on the outer shelf of Florida, in a 35-to-65-mdeep, quiet-water environment (Prager and Ginsburg, 1989). It is thus interpreted that the source area of these redeposited clasts was the outer shelf.

The modern, shallow-water coralline association in the Pacific reefs, dominated by mastophoroids, has not been detected in any of the sediments drilled in the Queensland Plateau. Species formerly included in Porolithon Foslie, Goniolithon Foslie, or Paraporolithon Johnson are characteristic of the algal ridges and other shallow-water environments in Neogene (Johnson, 1961) and in present-day (Foslie, 1907; Setchell, 1928; Littler and Doty, 1975) Pacific reefs. The absence of these corallines and of other components of shallow-water coralline associations, such as members of the subfamily Lithophylloidea (Littler and Doty, 1975; Adey, 1979), supports the hypothesis of a relatively deep-water origin for most of the recorded corallines in Neogene sediments of the Queensland Plateau.

\section{CONCLUSIONS}

At all sites drilled in the Queensland Plateau during Leg 133, coralline algae were found throughout the Tertiary, albeit with an incomplete record.

In the temperate platform carbonates of the Eocene-Oligocene, coralline remains, unfortunately, are poorly preserved and cannot be identified, except in the case of some brief, tropical, coral-rich episodes in the middle Eocene, which contain fragments of Lithoporella, Mesophyllum, and Spongites.

Fragments of Spongites and Lithoporella, together with abundant geniculate corallines (Jania, Corallina, Amphiroa), can be found incorporated in sand bars in lower Miocene sediments. They represent an original shallow-water association. In redeposited sediments of the same age, an outer-shelf assemblage of Mesophyllum and Lithothamnion appears together with the geniculate corallines.

In the middle Miocene sequence, the algal associations consist of Lithothamnion, Sporolithon, Mesophyllum, Hydrolithon, and 
Aethesolithon. The predominant growth forms are branching and thinly laminar in loose fragments and small rhodoliths. All this, together with the abundance of micrite, points to a low-energy, outershelf environment.

In the early Pliocene section, foralgaliths of Lithoporella and encrusting foraminifers (which formed in an outer-shelf setting and were later redeposited in deeper areas) are the only elements found.

The present-day, shallow-water reef association in the Pacific Ocean, dominated by mastophoroids (i.e., species formerly included in Porolithon Foslie), has not been detected in any of the sediments drilled in the Queensland Plateau.

\section{ACKNOWLEDGMENTS}

We thank the crew and scientific party of Leg 133 for their logistic and scientific support, and ODP for samples. JMM is grateful to the Spanish Consortium for the Ocean Drilling Program, which supported his participation during this cruise. We would like to thank B. Buchbinder, as well as an anonymous referee, for the critical reading and suggestions to improve the paper.

\section{REFERENCES}

Adey, W.H., 1979. Crustose coralline algae as microenvironmental indicators in the Tertiary. In Gray, J., and Boucot, A.J. (Eds.), Historical Biogeography, Plate Tectonics and the Changing Environment: Corvallis (Oregon State Univ. Press), 459-464.

Adey, W.H., and McIntyre, I.G., 1973. Crustose coralline algae: a re-evaluation in the geological sciences. Geol. Soc. Am. Bull., 84:883-904.

Bosence, D.W.J., in press. Miocene coralline algae and coralline algae facies. In Jordan, C., Colgan, M., and Esteban, M. (Eds.), Miocene Reefs: a Global Comparison: Berlin (Springer-Verlag).

Foslie, M.H., 1907. The lithothamnia of the Percy Sladen Trust expedition in HMS Sealark. Trans. Linn. Soc. London, Zool. Ser., 2:93-100.

Johnson, J.H., 1961. Limestone-building Algae and Algal Limestones: Boulder (Colorado School of Mines).

1964. Fossil and Recent calcareous algae from Guam. Geol. Surv Prof. Pap. U.S., 403-G:1-40.

Lemoine, P., 1976. Le genre Lithoporella Foslie (algue Rhodophycée Corallinacée) au Tertiare et au Quaternaire. Bull. Soc. Geol. Fr., 18:773-787.
Littler, M.M., and Doty, M.S., 1975. Ecological components structuring the seaward edge of tropical Pacific reefs: the distribution, communities and productivity of Porolithon. J. Ecol., 63:117-129.

Prager, E.J., and Ginsburg, R.N., 1989. Carbonate nodule growth on Florida's outer shelf and its implications for fossil interpretations. Palaios, 4:310317

Setchell, W.A., 1928. A botanical view of coral reefs, especially those of the Indo-Pacific region. Proc. 3rd Pac. Sci. Congr., 1137-1143.

Shipboard Scientific Party, 1991a. Principal results and summary. In Davies, P.J., McKenzie, J.A., Palmer-Julson, A., et al., Proc. ODP, Init. Repts., 133: College Station, TX (Ocean Drilling Program), 59-72.

, 1991b. Sites 811/825. In Davies, P.J., McKenzie, J.A., Palmer-Julson, A., et al., Proc. ODP, Init. Repts., 133 (Pt. 1): College Station, TX (Ocean Drilling Program), 73-134.

. 1991c. Site 812. In Davies, P.J., McKenzie, J.A., Palmer-Julson, A., et al., Proc. ODP, Init. Repts., 133 (Pt. 1): College Station, TX (Ocean Drilling Program), 135-176.

, 1991d. Site 813. In Davies, P.J., McKenzie, J.A., Palmer-Julson, A., et al., Proc. ODP, Init. Repts., 133 (Pt. 1): College Station, TX (Ocean Drilling Program), 177-202.

-, 1991e. Site 814. In Davies, P.J., McKenzie, J.A., Palmer-Julson, A., et al., Proc. ODP, Init. Repts., 133 (Pt. 1): College Station, TX (Ocean Drilling Program), 203-242.

1991f. Site 817. In Davies, P.J., McKenzie, J.A., Palmer-Julson, A., et al., Proc. ODP, Init. Repts., 133 (Pt. 1): College Station, TX (Ocean Drilling Program), 345-416.

1991g. Site 823. In Davies, P.J., McKenzie, J.A., Palmer-Julson, A., et al., Proc. ODP, Init. Repts., 133 (Pt. 1): College Station, TX (Ocean Drilling Program), 679-768.

199lh. Site 824. In Davies, P.J., McKenzie, J.A., Palmer-Julson, A., et al., Proc. ODP, Init. Repts., 133 (Pt. 1): College Station, TX (Ocean Drilling Program), 769-804.

"Abbreviations for names of organizations and publications in ODP reference lists follow
the style given in Chemical Abstracts Service Source Index (published by American Chemical Society).

Date of initial receipt: 11 March 1992

Date of acceptance: 10 December 1992

Ms 133SR-243 

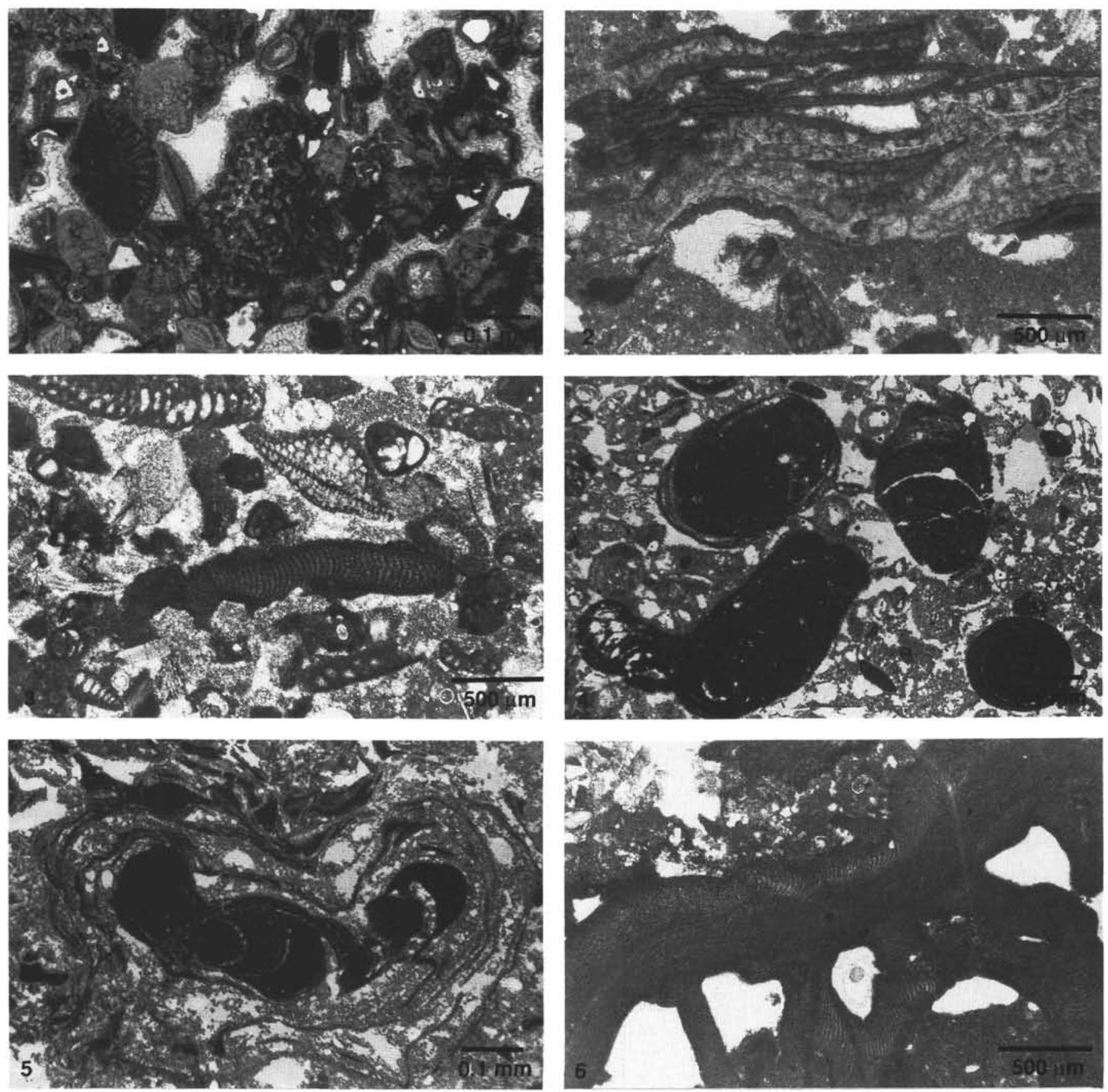

Plate 1. 1. Photomicrograph of a bioclastic floatstone from the middle Eocene with benthic foraminifers, corals (Porites), and coralline remains. Sample 133-825B-7R-1, 32-33 cm. (Scale bar $=1 \mathrm{~mm})$. 2. Photomicrograph of a sample $(133-824 \mathrm{~A}-30 \mathrm{X}-\mathrm{CC}, 0-17 \mathrm{~cm})$ from the lower Miocene showing interlaminated Lithoporella growing on foraminifers. (Scale bar $=500 \mu \mathrm{m}$ ). 3. Middle Miocene bioclastic floatstone with redeposited lower Miocene bioclasts (mainly corallines and benthic forams) and intraclasts. A fragment of the geniculate alga Jania stands out clearly in the center. Sample $133-823 \mathrm{C}-13 \mathrm{R}-2,122-125 \mathrm{~cm} .(\mathrm{Scale}$ bar $=500$ $\mu \mathrm{m})$. 4. Branching growths of Sporolithon in a packstone of middle Miocene age. Sample 133-812B-7R-1, 25-26 cm. (Scale bar =1 mm). 5. A small rhodolith having a nucleus of branching Sporolithon encrusted by laminar Lithothamnion and foraminifers. Sample 133-812A-18X-1, 7-8 cm. (Scale bar = $1 \mathrm{~mm}$ ). 6. A fragment of a lower Miocene rhodolith consisting mainly of Mesophyllum in redeposited middle Miocene sediments. Sample 133-817D-23R-1,27-30 cm. (Scale bar $=500 \mu \mathrm{m})$. 

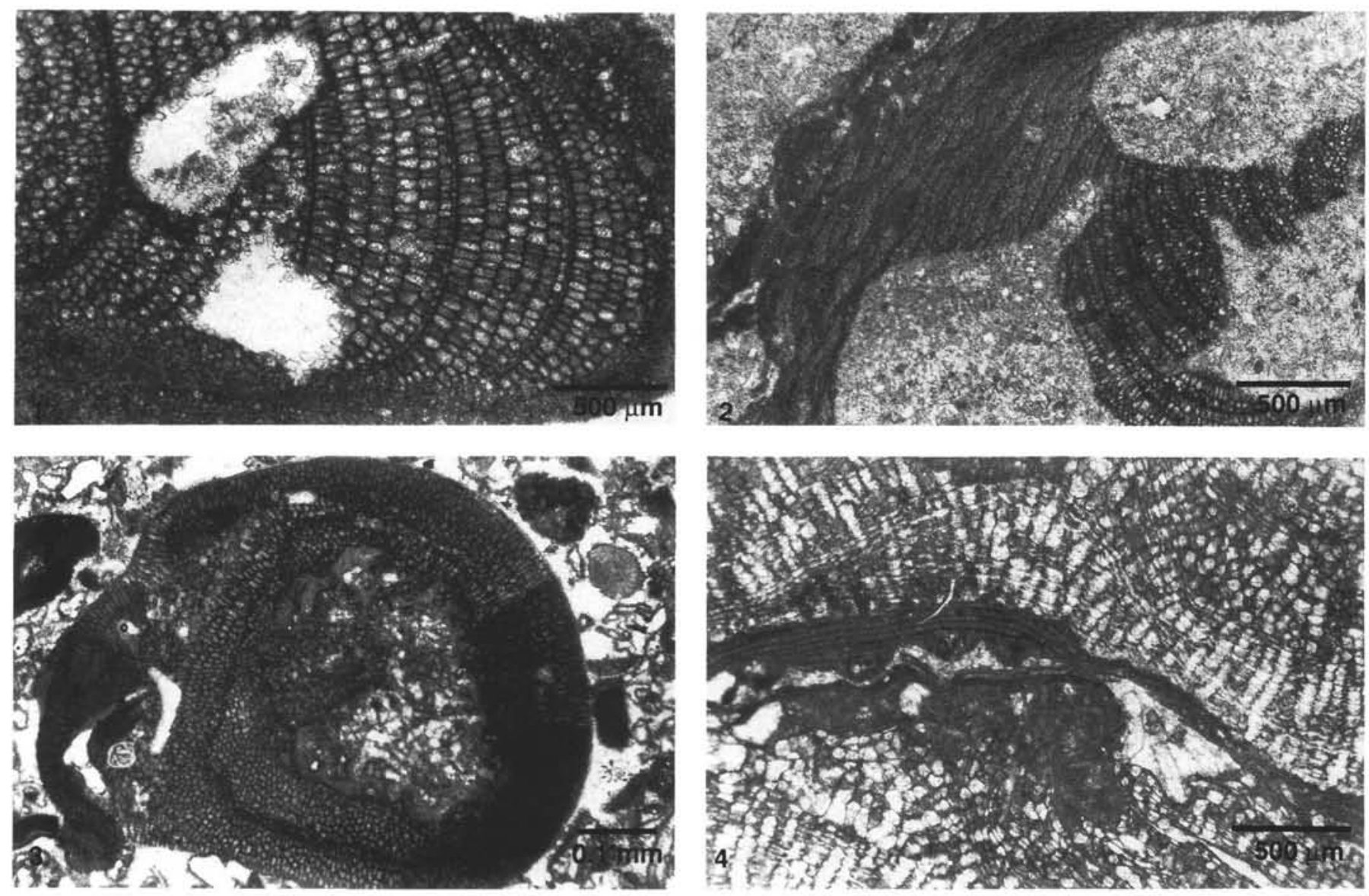

Plate 2. 1-2. Aethesolithon thalli bored by sponges. Middle Miocene. Samples 133-812B-10R-1, 24-25 cm, and 133-812B-7R-1, 127-128 cm. (Scale bars = $500 \mu \mathrm{m})$. 3. A foralgalith in a lower Pliocene rudstone. Sample 133-824A-10H-1, $84-88 \mathrm{~cm}$. (Scale bar $=1 \mathrm{~mm}$ ). 4. A close-up of a lower Pliocene foralgalith showing thin laminae of Lithoporella between thick layers of encrusting foraminifers. Sample 133-824A-10H-1, $75-77 \mathrm{~cm}$. (Scale bar $=500 \mu \mathrm{m})$. 